\title{
Feeding Habits, Fine Structure and Microhabitat Preference of Euthyplocia hecuba (Hagen, 1861) (Ephemeroptera: Euthyplociidae) Nymphs from Honduras
}

\author{
Stefano FenOGLIO, Tiziano Bo, Artur CzEKAJ, and Elżbieta RoŚcISZEWSKA
}

Accepted October 10, 2007

\begin{abstract}
Fenoglio S., Bo T., CZEKAJ A., RośCiszewSKA E. 2008. Feeding habits, fine structure and microhabitat preference of Euthyplocia hecuba (Hagen, 1861) (Ephemeroptera: Euthyplociidae) nymphs from Honduras. Folia biol. (Kraków) 56: 43-49.

The Euthyplociidae are a tropical and subtropical Ephemeropteran group. The aim of this study was to augment knowledge on some aspects of the biology and ecology of Euthyplocia hecuba (Hagen, 1861) nymphs. Mayflies were collected in the Rio El Padre, located on the Caribbean slope of Honduras. Diet, microhabitat preference and some fine morphological aspects of the nymphs were examined. E. hecuba nymphs are very specialised organisms that occupy a specific ecological niche in the lotic/benthic community. Immature stages show an evident preference for life in soft and fine substrata. They are detritivorous burrowers that ingest large amounts of fine particles deposited by river flow in sedimentation areas. They show peculiar morphological adaptations for life in this particular substratum, such as mouthparts modified for digging and collection of fine organic sediments, digging legs with shovel-like tibiae and massive femora, and filamentous gills.
\end{abstract}

Key words: Euthyplocia hecuba, Euthyplociidae, Ephemeroptera, neotropics, ecology, morphology.

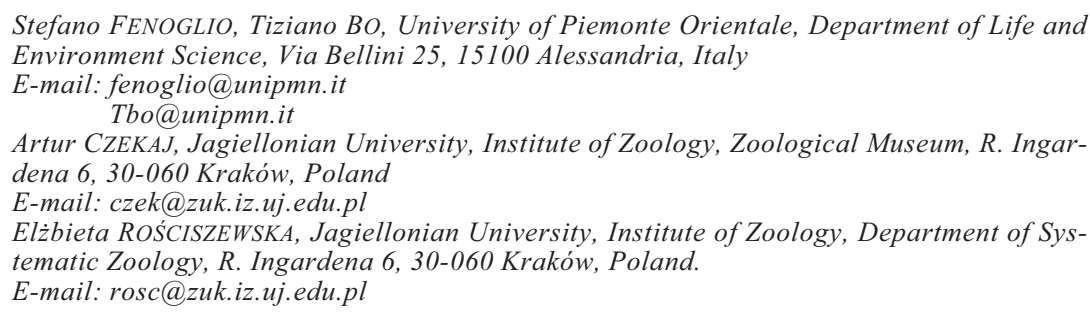

The Euthyplociid mayflies are tropical and subtropical ephemeropterans (KLUGE 2003) that have been subjected to taxonomic revision and some debate (DOMINGUEZ et al. 2002; NGUYEN \& BAE 2003; MERCADO \& ELLIOTT 2006). Currently some authors consider this group as one of six subfamilies of the family Polymitarcyidae (MCCAFFERTY 1991; NGUYEN \& BAE 2003), while other authors elevate this taxon to the family level (PETERS \& CAMPBELL 1991). In Central America there are two genera in this group: Euthyplocia, reported from Belize, Costa Rica, Guatemala and Panama, and Campylocia, reported from Costa Rica (NARANJO \& TERUEL 2001).

Euthyplocia is a small genus, composed of only four species: E. hecuba (Hagen, 1861), E. haenshi (Ulmer 1942), E. intermedia (Demoulin 1952) and E. inacessibile (Kluge \& Naranjo 1994). After the pioneering studies of DEMOULIN (1952, 1966), BERNER and THEW (1961) and others, studies con- cerning this group have been mainly taxonomic and based on "classical" entomological descriptions. Recently, SWEENEY et al. (1995) studied the life history characteristics of $E$. hecuba, investigating larval development and seasonal emergence. This work provided the first evidence for semivoltinism in the tropical mayfly. The aim of this note is to augment the information on these tropical mayflies using gut content examination, direct observation in the field, and ultrastructural SEM analysis.

\section{Material and Methods}

The study was conducted in the Río El Padre (16P0536344 UTM 1732416), a tributary of Río Cangrejal, Honduras (Fig. 1). The Cangrejal district, situated on the Caribbean coast of Honduras, is one of the areas of greatest ecological integrity 


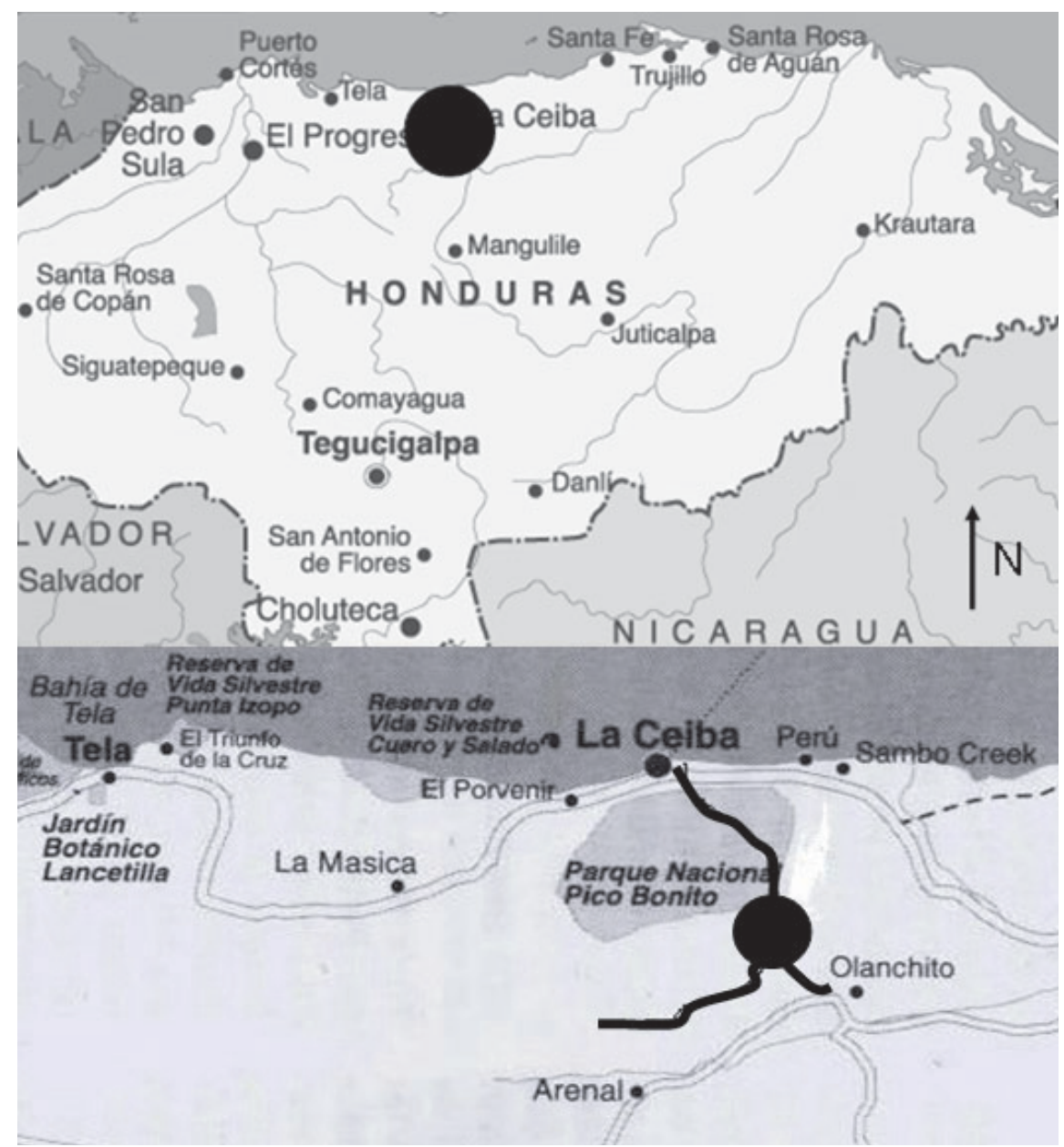

Fig. 1. Map of Honduras (black points signal sampling area and sampling station in the Rio El Padre).

of Central America and is characterized by a humid tropical climate and intense precipitation (FENOGLIO 2005).

\section{Feeding habits}

To investigate the diet, the contents of alimentary canals were analysed using the transparency method for slides according to C. L. Bello (FENOGLIO \& TiERNO DE FIGUEROA 2003). Eight specimens were kept in vials containing Hertwig's liquid (a variation of Hoyster's liquid - FENOGLIO et al. 2007) and placed in an oven for 24 hours at $65^{\circ} \mathrm{C}$. Then they were mounted on slides with Faure's liquid and examined with transmitted light with an Axiovert 100M microscope. For each specimen, the absolute content percentage of the gut was measured (calculated as the percentage of occupied area in the gut $-40 x$ ), and the typology and the relative importance of the different food items was assessed (400x).

\section{Microhabitat preference}

A total of 12 Surber samples (area $0.06 \mathrm{~m}^{2}$, mesh $250 \mu \mathrm{m})$ were collected from a 50-m long stretch of the Rìo El Padre on a single occasion (8 July 2005), to minimize temporal variation of invertebrate distribution. Water temperature was $28.5^{\circ} \mathrm{C}$, $\mathrm{pH}$ was 7.7 and dissolved oxygen was $23.1 \mathrm{mg} / \mathrm{l}$. Benthic invertebrate samples were fixed in ethanol $(75 \%)$ and subsequently examined in the laboratory with a stereoscopic Nikon SMZ 1500 microscope (20/90 X). To investigate spatial distribution patterns, current velocity, water depth and distance from the nearest stream bank were measured at each Surber sample. Percentages of different substratum sizes (boulders $>25-45 \mathrm{~cm},>$ cobble $6-25 \mathrm{~cm}$, >gravel $6-60 \mathrm{~mm}$, sand 0.06-6 mm, silt $<0.06 \mathrm{~mm}$ ) were recorded and current speed was determined at each point. Statistical analysis of the relationships between invertebrate distribution and the selected environmental parameters was performed with Principal Component Analysis (PCA) and Canonical Correspondence Analysis (CCA).

\section{Ultrastructural analysis}

We analysed mouthparts, legs and tracheal gills of Euthyplocia hecuba nymphs using a Jenalumar 
(Zeiss Jena) light microscope (LM) and a scanning electron microscope SEM JEOL 5410, $25 \mathrm{kV}$. The material for SEM was dehydrated in a series of ethanol and acetone, dried at the critical point of $\mathrm{CO}_{2}$ and coated with gold.

\section{Results}

Feeding habits and microhabitat preferences

The guts of eight specimens were examined. None were empty, on the contrary all guts showed high absolute content percentages: mean percentage of occupied area was 88.7 , with a minimum of $80 \%$ and a maximum of $100 \%$ of total gut area. Microscopic analysis revealed that all nymphs had fed on fine detritus. Guts were filled with fine organic and inorganic particles, with the sporadic oc- currence of diatoms (found in two guts). Quantitative sampling was performed for the assessment of habitat preferences, collecting a total of 792 organisms and 24 taxa (Table 1). The invertebrate assemblages within the examined stream section were characterized by noticeable spatial variation: both invertebrate density and taxonomic richness increased with increasing current velocity (Pearson's correlation $\mathrm{r}=0.89, \mathrm{P}<0.001)$ and riverbed component dimensions (Fig. 2): coarse sediment with rapid current was inhabited by richer communities of stream invertebrates, as reported in other studies in Neotropical streams (FENOGLIO et al. 2004). A sandy substratum was inhabited by a few specialised taxa: in this context, we detected a clear microhabitat preference of Eutyplocia nymphs for depositional areas, with fine elements (Fig. 3); interestingly, sediments inhabited by Euthyplocia nymphs seem to be well oxygenated, without hypoxia or anoxia conditions.

\section{Table 1}

Benthic invertebrates found in the stream stretch inhabited by $E$. hecuba nymphs, with main Functional Feeding Groups (FFG: collectors-gatherers $-\mathrm{Cg}$, filterers $-\mathrm{F}$, predators $-\mathrm{P}$, scrapers - Sc, shredders - Sh)

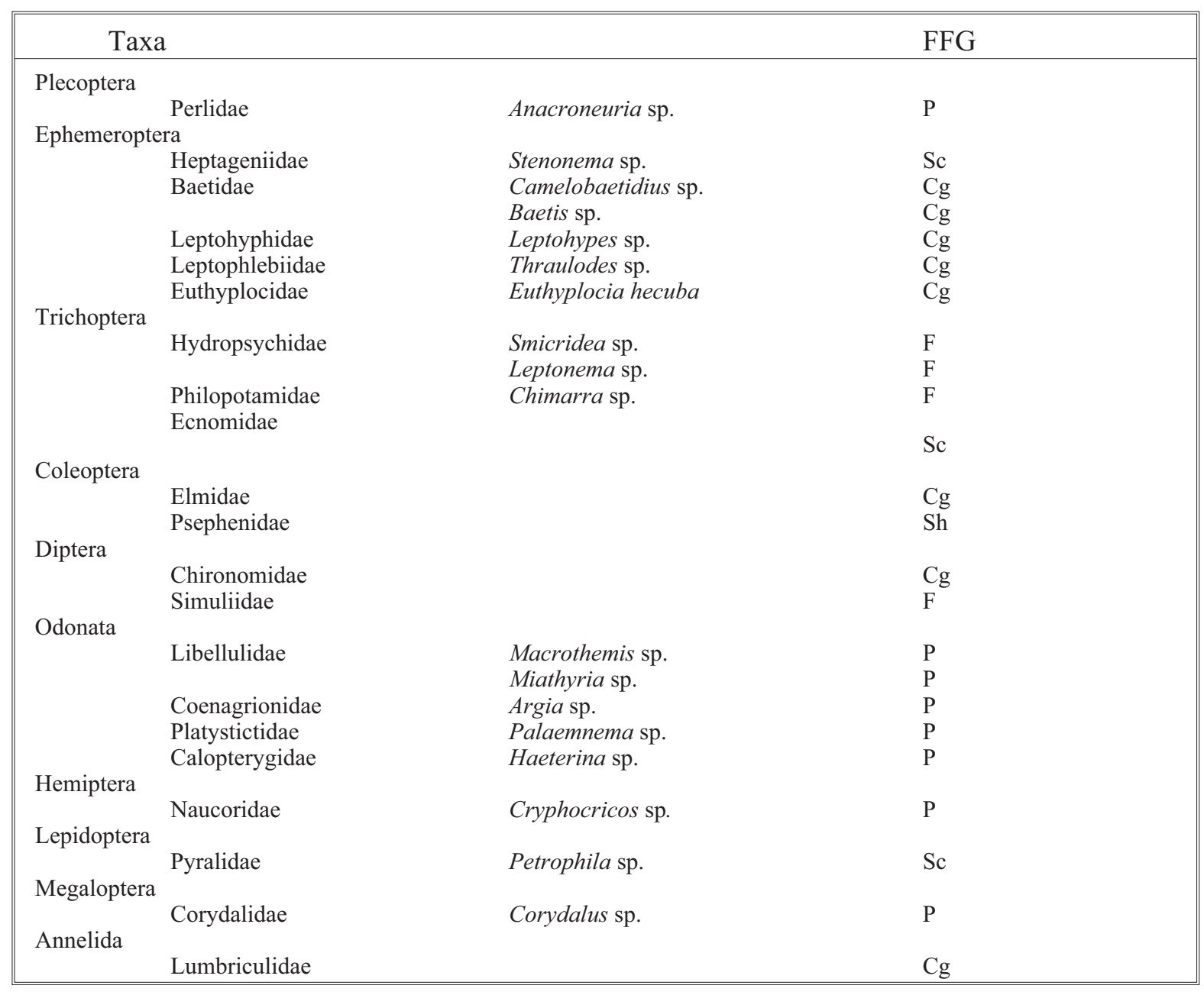




\section{Principal Component Analysis (75\%)}

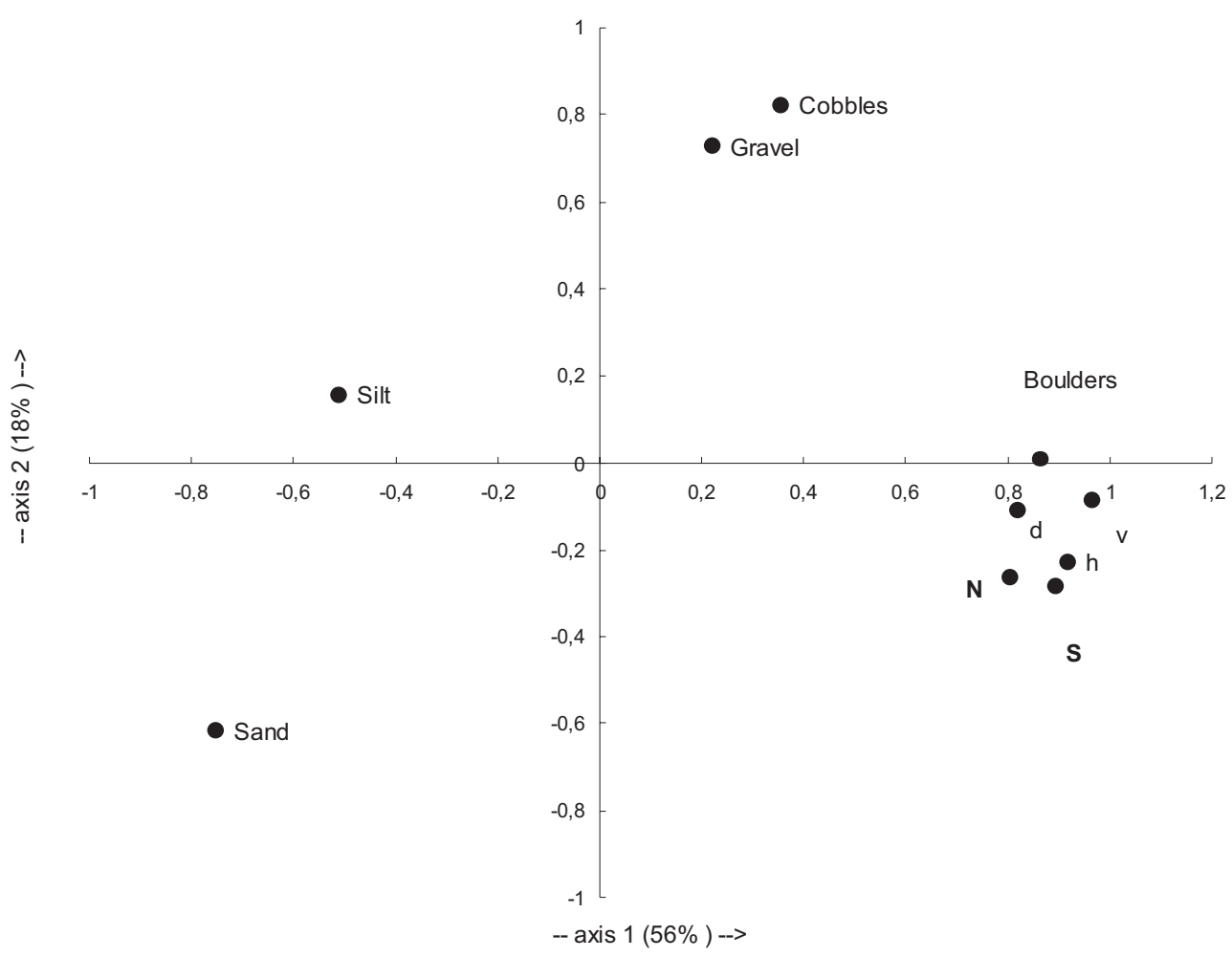

Fig. 2. Principal Component Analysis (v-current velocity; $d$ - distance from the nearest bank; $\mathrm{h}$ - water height above riverbed; $\mathrm{N}$ - invertebrate abundance; $\mathrm{S}$ - taxonomical richness; Boulders - \% of boulders in the substratum; Cobbles - \% of cobbles; Silt $-\%$ of silt; Sand $-\%$ of sand; Gravel $-\%$ of gravel).

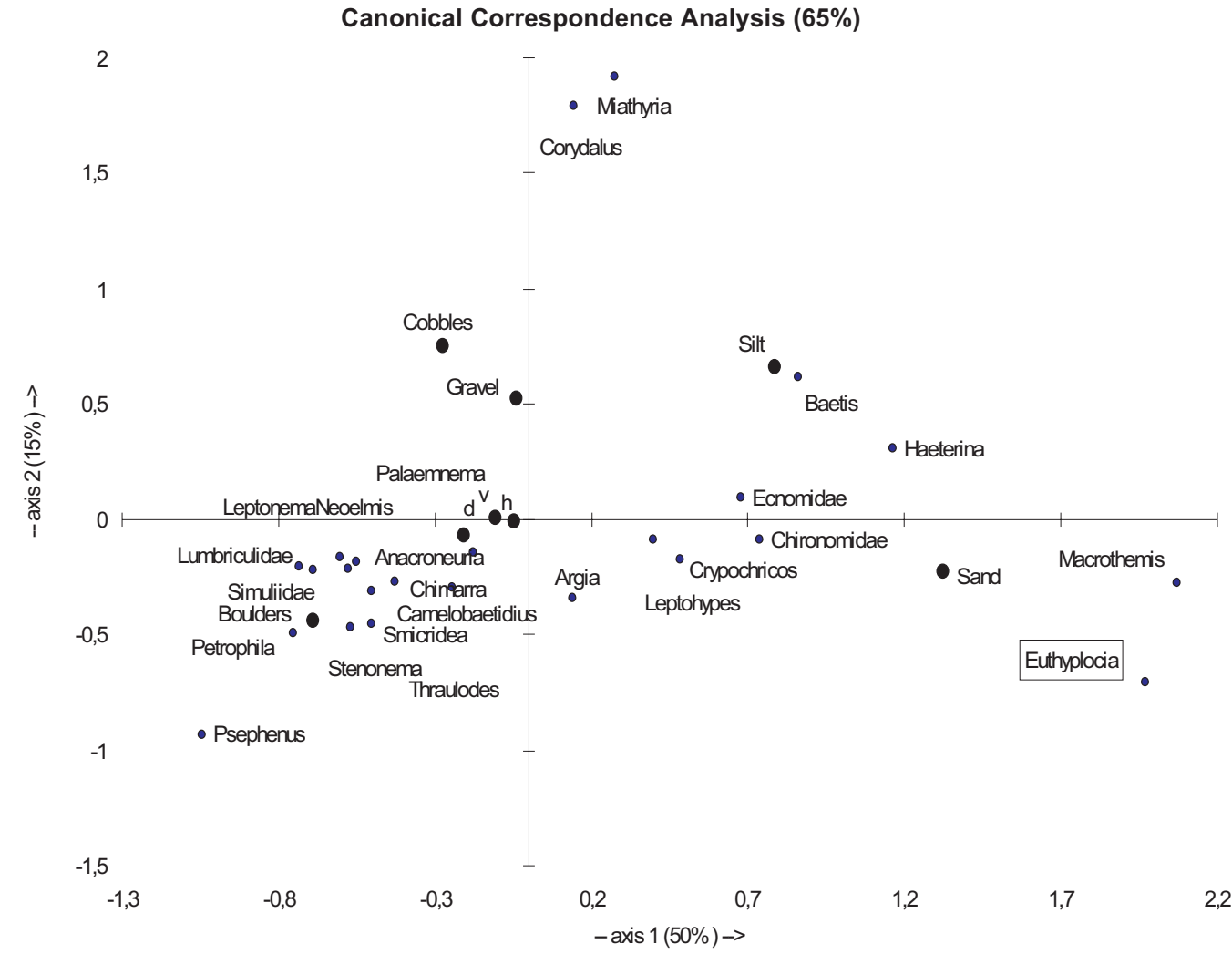

Fig. 3. Canonical Correspondence Analysis ordination of macroinvertebrates and microhabitat characteristics in Rio El Padre (v - current velocity; $d$ - distance from the nearest bank; $h$ - water height above riverbed; Boulders - \% of boulders in the substratum; Cobbles $-\%$ of cobbles; Silt - \% of silt; Sand - $\%$ of sand; Gravel $-\%$ of gravel). 


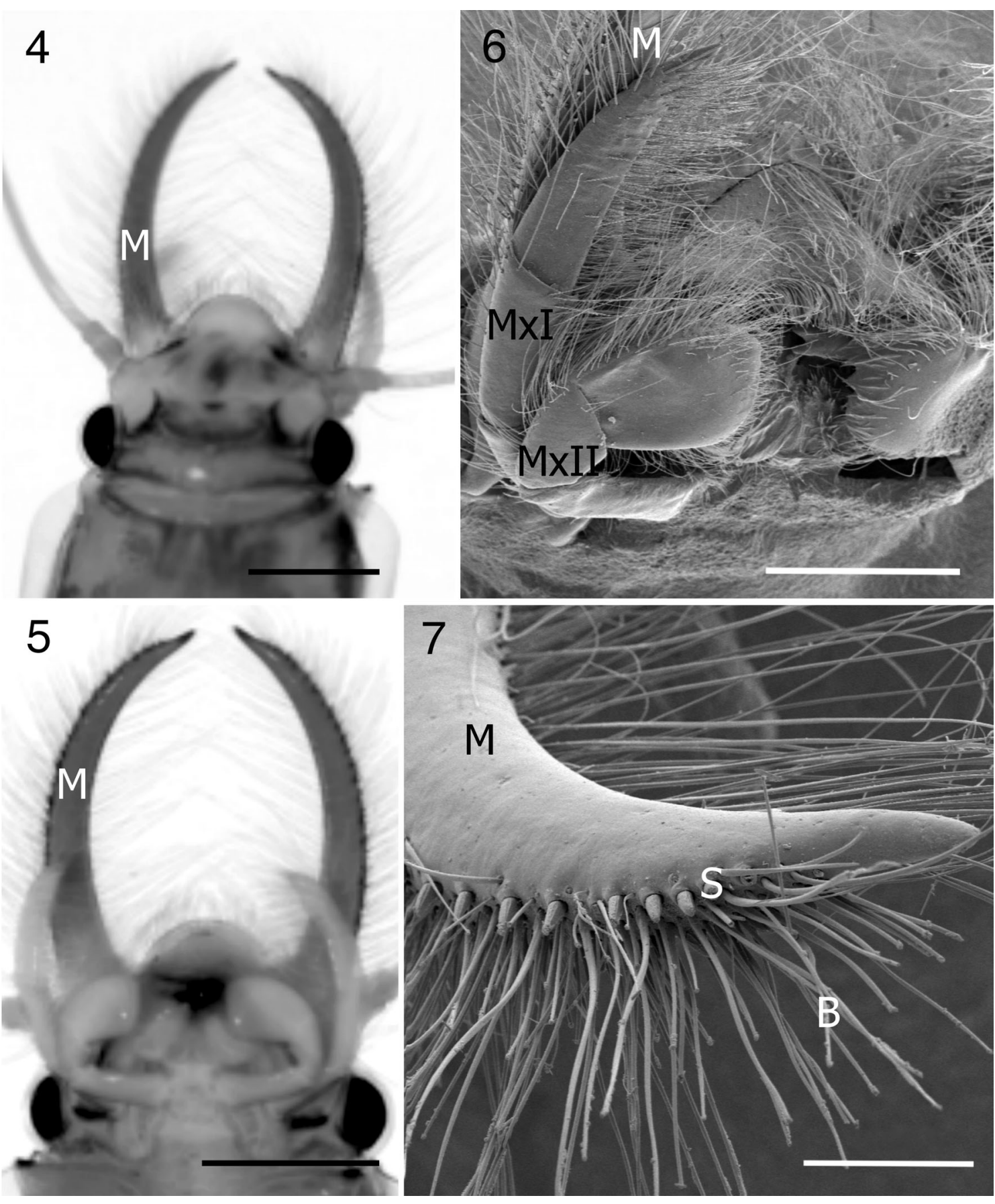

Figs 4-7. Euthyplocia hecuba nymph, light microscope (LM) and scanning electron microscope (SEM) studies. Fig. 4. Dorsal view of the head. LM. Bar $=1 \mathrm{~mm}$. Fig. 5. Ventral view of the head. LM. Bar =1mm. Fig. 6. An enlarged fragment of the head; ventral view. Note mouthparts characterised by long bristles. SEM. Bar $=600 \mu \mathrm{m}$. Fig. 7. A fragment of the mandible. Note the spiny-like dagger and a long bristles. SEM. Bar $=180 \mu \mathrm{m}$.

$\mathrm{B}$ - bristle; M - mandible; MxI - maxillae I; MxII - maxillae II; S - spiny-like dagger.

Ultrastructural analysis

Mouthparts: some interesting peculiarities were evidenced by the SEM analysis. First, all components of the mouth show high densities of long and fine bristles (Figs 4,5,6). They cover extensive areas of maxillae, mandibles and labial palps. The elongated and scimitar-like mandibles are equipped with long bristles and two lines of short and robust spikes (Fig. 7) that run along the external edge of the mandible.

Legs: some interesting elements were found on pronotal and metanotal legs The foreleg (Fig. 8) is very robust and compact, with tibia showing a sharpened appendix, tarsus reduced and mainly constituted of a compact third tarsomerus and claw. The hindleg is characterised by a massive femur (Fig. 9) and robust tarsus and claw. 

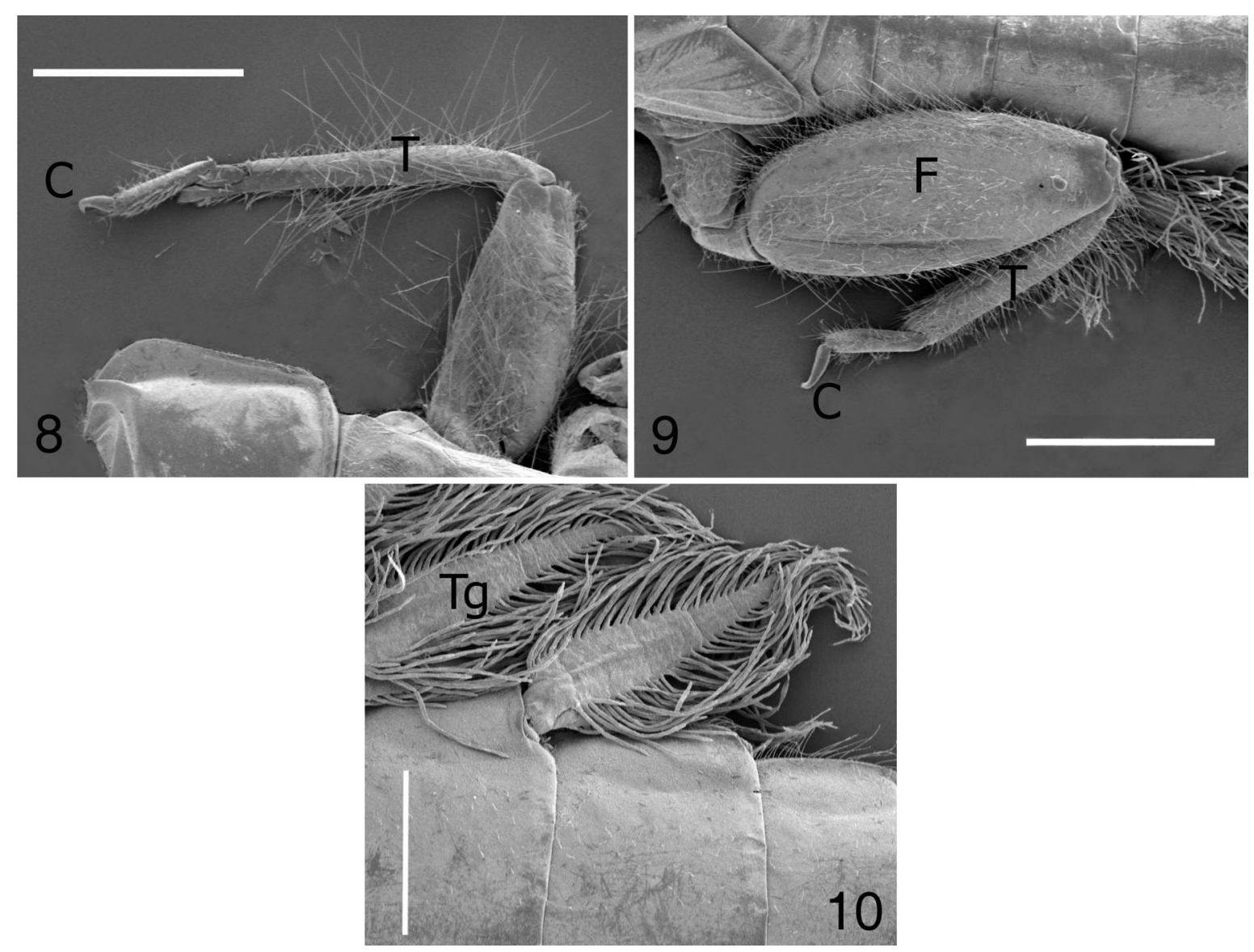

Figs 8-10. Euthyplocia hecuba nymph, light microscope (LM) and scanning electron microscope (SEM) studies. Fig. 8. A foreleg. Note its compact structure and the robust complex of tarsus and claw. SEM. Bar $=1800 \mu \mathrm{m}$. Fig. 9. A hindleg. Note the massive femur and elongate claw. SEM. Bar $=1800 \mu \mathrm{m}$. Fig. 10. The dagger-like, tracheal gills of abdominal segments are characterised by long filaments. SEM. Bar $=800 \mu \mathrm{m}$.

$\mathrm{C}$ - claw; F - femur; T - tibia; Tg - tracheal gill.

Gills: Tracheal gills are located along the sides of abdominal segments. Euthyplocia nymphs have filamentous gills, constituted by a triangular, elongate, dagger-like structure with two lateral lines of long filaments (Fig. 10).

\section{Discussion}

In this study several characteristics of Euthyplocia hecuba nymphs were analysed. The results corroborate previous findings (SWEENEY et al. 1995), showing that the diet of these organisms is based on the ingestion of large amounts of organic sediment. All guts examined were filled with sediment; the need to acquire large amounts of detritus probably stems from the low energetic value of this aliment. On the contrary, SWEENEY et al. (1995) reported that $E$. hecuba nymphs were almost always associated with the underside of small to large cobbles that were embedded about $25 \%$ or more into sandy substrate, however, they collected larvae by inspecting only coarse substrata. In this study, larvae were mostly found in sandy banks, either in the middle or in the lateral parts of the riverbed. In this substratum they are able to excavate tunnels and pass through fine substrata, thanks to particular morphological adaptations. The ultrastructural analysis suggested that digging is facilitated by the presence of: (1) long and curved mandibles, with lateral lines of robust tooth-like appendices, useful for moving fine elements of soft-bottom habitats; (2) compact and shovel-like tibiae and robust claws; (3) massive femora of hindlegs, allowing a powerful shove into the sediment. In this context the presence of fine and large bristles on the different elements of the mouth apparatus facilitates the collection of larger quantities of fine detritus deposited in the hydrologically quiescent areas of the riverbed. The long bristles present on the mandibles and on other mouthparts create a conic-shaped net structure that intercepts and convoys fine particles of organic detritus. Recent studies performed in temperate (STATZNER \& HOLM 1982; JAŻDŻEWSKA 1997) and tropical (FENOGLIO et al. 2004) lotic environments have 
demonstrated that sand is a biologically poor substrate, probably because of its instability and also because tight packing of sand grains reduces the trapping of organic detritus and limits the availability of oxygen. Also in this study, benthic invertebrate abundance and taxonomic richness was higher in coarse substrata and lower in fine ones. To survive in depositional environments, away from turbulent, fast-flowing and well oxygenated waters, this group of mayflies has evolved particularly adapted morphological elements, among which the gills play a key role. While rheostenic and rheophilous mayflies, such as Heptagenoidea, have lamellar gills, the Euthyplociidae have dagger-like gills, surrounded by numerous, long filaments enlarging the surface of gas exchange. Filamentous tracheal gills usually have greater respiratory efficiency than lamellar tracheal gills due to tracheoles found in the respiratory epithelium directly under the cuticle (WICHARD 1979) that run parallel to each other along the longitudinal axis of the filaments.

Immature stages of Euthyplocia are highly specialised organisms, with adaptations for life in a specific river microhabitat.

\section{Acknowledgements}

We wish to thank E. TENORIO, R. JORDAN and all the USAID-MIRA project staff that invited one of us (Stefano FENOGLIO) to Honduras. We are very grateful to the following people from the Institute of Zoology, Jagiellonian University, Kraków: Prof. Elżbieta PYZA (Department of Cytology and Histology), for providing SEM facilities; Dr Zuzanna BANACH and Dr Jadwiga FABER (the same Department) for skilled assistance with SEM. Special thanks to Dr Beata SZYMAŃSKA (Department of Systematic Zoology and Zoogeography) for professional help with preparing illustrations. The investigations were in part supported by Research Grant BW/IZ/24b/2004 to Elżbieta ROŚCISZEWSKA.

\section{References}

BERNER L., THEW T. B. 1961. Comments on the mayfly genus Campylocia, with a description of a new species (Euthyplociidae: Euthyplociinae). Amer. Midland Naturalist 66: 329-336.
Demoulin G. 1952. Contribution l'tude des Ephoronidae Euthyplociinae (Insectes Ephmroptres). Bull. Inst. Roy. Sci. Nat. Belg. 28: 1-22.

DEMOULIN G. 1966. Contribution 1'tude des Euthyplociidae III (Insectes Ephmroptres). Zoologishe Mededelingen 41: 137-141.

DOMinguez E., ZunigA M. C, MOLINERI C. 2002. Estado actual del conocimiento y distribution del ordenEphemeroptera (Insecta) en la Region Amazonica. Caldasia 24: 459-469.

FENOGLIO S. 2005. Ecological quality and benthic invertebrates communities in the Rio Cangrejal basin. La Ceiba, Honduras, USAID-MIRA, Internal report.

FEnOGLIO S., TIERnO de FigueroA J. M. 2003. Observation on the adult feeding of some Neoperla and Anacroneturia species (Plecoptera, Perlidae). Afr. Ent. 11: 138-139.

Fenoglio S., Bo T., CuCCO M. 2004. Small-scale macroinvertebrate distribution in a Neotropical Rainforest Stream. Carrib. J. Science 40: 253-257.

Fenoglio S., Bo T., Pessino M., Malacarne G. 2007. Feeding of Perla grandis nymphs (Plecoptera: Perlidae) in an Apennine first order stream (Rio Berga, NW Italy). Ann. Soc. Ent. Fr. 43: 221-224.

JAŻDŻEWSKA T. 1997. Mayflies (Ephemeroptera) of the sandy bottom of the river Grabia (Central Poland). Proc. of eight Intern. Conf. on Ephemeroptera and twelfth Intern. Symp. on Plecoptera. Landolt P, Sartori M. eds. August 1995, Lausanne. Museum of Zoology in Lausanne and University of Fribourg. Biology-Ecology-Systematics. Mauron+Tinguely\&Lachat SA Publishers: 157-166.

KLUGE N. J. 2003. System and phylogeny of Pinnatitergaliae (Ephemeroptera). (In: Research Update on Ephemeroptera and Plecoptera. E. Gaino ed. University of Perugia, Perugia): 145-152.

MC CAFFERTY W. P. 1991. Toward a phylogenetic classification of the Ephemeroptera (Insecta). a commentary on systematics. Annual Entomological Society of America 4: 343-360.

MERCADO M., ELliotT S. 2006. Taxonomic revision of the genus Chaquihua Demoulin (Ameletopsidae: Ephemeroptera) with notes on its biology and distribution. Studies on Neotropical Fauna and Environment 41: 59-66.

NARANJO C., TERUEL R. 2001. Nuevos registros de localidad para Euthyplocia inaccessibile Kluge \& Naranjo, 1994 y Hagenulus (Traverina) oriente Kluge, 1993 (Ephemeroptera. Euthyplociidae, Leptophlebiidae). Bol. S.E.A. 29: 47-48.

NGUYEn V. V, BAYE Y. J. 2003. A new Euthyplociid burrowing mayfly (Ephemeroptera: Euthyplociinae, Polymitracyidae) from Vietnam. Korean J. Biol. Sci. 7: 279-282.

Peters W. L., CAMPBELL I. C. 1991. Ephemeroptera. (In: Insects of Australia, vol. I. I. D. Naumann, P. B. Carne, J. F. Lawrence, E. S. Nielsen, J. P. Spradberry, R. W. Taylor, M. J. Whitten, M. J. Littlejohn eds. Melbourne University Press, Victoria): 279-293.

STATZNER B., HOLM T. F. 1982. Morphological adaptations of benthic invertebrates to stream flow. an old question studied by means of a new technique (Laser Doppler Anemometry). Oecologia 53: 290-292.

SWEENEY B. W., JACKSON J. K., FUNK D. H. 1995. Semivoltinism, seasonal emergence, and adult size variation in a tropical stream mayfly (Euthyplocia hecuba). J. N. Am. Benthol. Soc. 14: 131-146.

WICHARD W. 1979. Structure and function of the respiratory epithelium in the tracheal gills of mayfly larvae. Proc. 2nd Intern. Conf. on Ephemeroptera, Kraków: 307-309. 